\title{
Some Recent Mammal Records
}

by R. W. Nero, Saskatchewan Museum of Natural History

The Museum regularly receives a variety of animals submitted for identification from readers of tre Blue Jay and the general public. All of these specimens provide valuable distribution data and are processed accordingly. A few recent mammal records, however, warrant special attention.

Pygmy Shrew (Microsorex hoyi) - two specimens, both captured in a cesspool at Naicam, Sask., on July 23, 1959, by Mrs J. Missler. Only half-a-dozen records are available for the province.

Small-footed Myotis (Myotis subulatus) - the second specimen for the province was collected on June 27, 1959, in the South Saskatchewan River Valley north of Main Centre by A. Swanston and B. McCorquodale who also found the first specimen (see Blue Jay, Dec., 1958). This specimen was found alive lying on the bare ground in a gully in a sandy outcrop after a rain.

Red Bat (Lasiurus borealis)-a male specimen sent in from Tullis, Sask., on Sept. 21, 1959, by Mrs. E. Barager, provides a new locality record.

Hoary Bat (Lasiurus cinereus)-a female with half-grown young was ccllected at Yorkton by Dr. S. Houston on July 19, 1959. (For information on other breeding data see Blue Jay, Sept., 1958).
Gray Squirrel (Sciurus carolinensis)-two previously unreported records; a pelt of an adult received from J. Provick, caught in a mink trap near Esterhazy, Sask., in January, 1958, and an adult female specimen received which was shot near granaries at Edenwold on March 11, 1959 , by G. Markel. These are both new locality records.

Olive-backed Pocket Mouse (Perognathus fasciatus)-Specimens are on hand from four new localities in Sask.; one at Boharm, May 13, 1959, taken by A. Swanston; one from Gainsborough, May 25, 1959, by $\mathbf{J}$. Reynolds; one from S. Sask. River valley nortt: of Main Centre, on July 7, 1959, by R. Nero; and one from McCord, Sept. 22, 1959, by E. Kuyt. An additional series of 14 was collected in two hours at night on Sept. 17,1959 , about 7 miles west of Hatfield in a previously reported locality.

The pocket mouse which was collectel at McCord was a female which had a greatly enlarged and discolored liver. It was submitted to $\mathrm{Dr}$. $\mathrm{H}$. O. Dillinger, bacteriologist at the Provincial Health Laboratory, Regina, who made the following diagnosis: the cause of the liver swelling and the yellow patches ras been ascertained as Capillaria hepatica, a whipworm. This parasite is a (Continued on page 173)

\section{Northern Records of the Woodchuck}

\section{by Peter Gregg, La Ronge}

Beck's Guide to the Mammals of Sask., (see Blue Jay, March, 1959, for review) records the Woodchuck (Marmota monax) in Prince Albert National Park, but has no records of this mammal occurring further north. Since moving to La Ronge this past summer I have seen them along Highway No. 2 from roughly Mile 80 (22 miles south of La Ronge) to the vicinity of the Potato Lakes at Mile 95 (about 7 miles south of La Ronge). The road mileage system starts with Mile 0 at Waskesiu and terminates at La Ronge which is about Mile 102. The mileage numbering on the Uranium City Road, of which 25 miles are now complete. starts at La Ronge with Mile 0 all over again.

In the area frequented by the woodchucks there are quite a few sandy banks where I suspect they have their burrows. I have looked at one road kill in July along the extent of road mentioned and on various trips have seen a total of 8 or 10 woodchucks along the roadside.

ED. NOTE: Dr. Gregg, formerly with the Dept. of Nat. Resources, is now working as a free-lance writer and has just recently moved to La Ronge. He holds a Ph.D. degree in conservation from Cornell University and is strongly interested in wilderness areas and life cut-of-docrs. We wish him lots of luck and hope to hear more from him about the La Ronge area. 
sive floras of North America. Genera are arranged alphabetically within families and species are arranged alphabetically within genera. This means that true phylogenetic relationships are not shown between species, genera or families. Some phylogenetic relationship is shown in the keys, for instance when a large genus, e.g., Carex which has 123 species in Alberta, is divided into sections. Dr. Moss explains that he r.as used an alphabetical arrangement to avoid use of numbers which would add to typesetting costs. However, one regrets that he has not used a natural arrangement which would show relationships as he sees them.

There will always be disagreements among botanists about the correct names for different species. Dr. Moss frankly admitted in conversation with me that tr:ere were many cases where he did not know just what to do about the names. Fortunately for those interested in plants of the western Canadian provinces he has not waited to settle all his doubts before publishing. Looking at some of the nomenclatural próblem spots I find that Dr. Moss has been conservative in his approach and I feel that he has made his decisions carefully. There will be some name changes in future editions. Botany is interesting partly because there is still so much to be learned and changes in names simply indicate our growing knowledge.

When I was in Alberta this past summer on the Grassland Tour which preceded the International Botanical Congress I added a number of Alberta plants to my collection. Some of these were new collections for my herbarium, like Danthonian parryi Scribn. from the Stavely Range Station and Saussurea densa (Hook) Rydb. from Tableau Mountain. I still have at least a half dozen unidentified plants which I shall look for in Dr. Moss' book. It is as such a working tool that the Flora of Alberta will prove most useful. People of Alberta are fortunate in now having a complete manual of the vascular plants of their province. It will be of considerable value in British Columbia and Saskatchewan, too, for in many genera exactly the same species occur in all trree provinces. - George F. Ledingham, Regina.
MUSHROOMS. By Albert Pilat and Otto Usak. Spring Books, London. $56 / 6$.

Produced after six years joint effort by this mycologist-artist team this book contains $1208 \times 11$ inch color prints of mushrooms at natural size showing gill structure, stem cross-section, and with color sketches of spores.

The introduction deals with the morphology, biology, anatomy and histology cf the higher mushrooms. There is a chapter on mycorrhiza, the symbiosis of mushrooms and trees. Propagation is discussed. There is a list of edible mushrooms, an analysis of nutritive value, a copy of the Czech food regulations, recipes and a chapter on mushrcom poisoning.

The bibliography lists works of Bolton, Buller, Fries, Ramsbottom, and Schaeffer, but not Christensen, Smith or Thomas Gussow and Odell are mentioned in the chapter on poisoning but not in the list. Apparently the author is more familiar with the works of Europeans than with those on this side of the Atlantic.

Among tr:e edible mushrooms the author considers Armillariella mellea inferior, a choice which is certain to be disputed by local mycophagists.

Any book of this size (340 pages) cannot include all the individual species of agarics, and several are not listed, however mushroomers will find it a valuable reference.-Tony Capusten, Prince Aibert.

C O N S E R ATION DIRECTORY (1959). A listing of Organizations and Officials concerned with Natural Resources. National Wildlife Federation, Washington, D.C. Price 50c.

A copy of this directory of organizations-government and private, national and regional-concerned with conservation, comes to our president, and anyone wishing to do so may borrow it. The directory includes international, and Canadian and Latin American, as well as American organizations.

\section{(Continued from page 169)}

selective rodent inhabitant and always chooses the liver for accumulation of its eggs. Two human cases have been described, one from India and one from Panama, possibly through eating of edible predator-meat. 